\title{
Re-Situating Information Poverty: Information Marginalization and Parents of Individuals with Disabilities
}

Amelia N. Gibson

School of Information and Library Science, University of North Carolina at Chapel Hill, Chapel Hill, NC, 27599. E-mail: angibson@email.unc.edu

John D. Martin III

School of Information and Library Science University of North Carolina at Chapel Hill, Chapel Hill, NC, 27599. E-mail: johnmar3@email.unc.edu

This is a preprint. The published version of this article can be found in the Journal of the Association for Information Science and Technology at https://doi.org/10.1002/asi.24128.

\begin{abstract}
This article outlines a constructivist grounded theory (Charmaz, 2014) study of information poverty among a group of mothers of individuals with Down syndrome and/or Autism Spectrum Disorders (ASD) from a critical perspective, drawing on concepts from critical disability theory, critical race theory, and critical work within information and library science. The researchers gathered interview data from 24 mothers. Resulting data were inductively analyzed using Chatman's (1996) theory of information poverty. We propose information marginalization as a complimentary concept to describe the contextual conditions that contribute to a range of defensive information behaviors and suggest that assessment of these contextual conditions be a part of the system design process. This study has implications for the development and design of systems and service models intended to provide access to information and services for individuals with disability and contributes to a critical literature on information poverty.
\end{abstract}


In one form or another, the concept of information inequity (i.e., the idea that some people have greater difficulty finding, accessing, accepting, or using information than others) has represented a core moral motivation for information behavior research since the turn toward user-centered research and practice (Britz, 2004; Mathiesen, 2015; Samek, 2007). The more specific concept of information poverty has been used to refer to a persistent lack of information access as experienced by a group or an individual, usually as a result of social factors, embodied by various types of information-related inequalities (e.g., chronic information illiteracy, lack of broadband access, or lack of information resources because of low income or education; Haider \& Bawden, 2007; Yu, 2006). Much of the theory around information poverty focuses on the behavior of the individual (experiencing "poverty") rather than the institution (creating "poverty"). This article pivots away from a focus on the individual toward development of a theory of information marginalization that describes the systematic, interactive socio-technical processes that can push and hold certain groups of people at social "margins," where their needs are persistently ignored or overlooked. Here, "technical" is used broadly, to include technology, information, data, formal policy, and informal, but normative person-to-person information processes employed within local communities and institutions (Jones \& Karsten, 2008; Orlikowski, 1992).

Chatman (1996), which theorized mechanisms of information poverty, is seminal in the context of library and information science research. Although information access issues might be resolved with the addition of resources or infrastructure, information poverty is more deeply imbedded into the social and political structure of a place, community, or institution. Chatman (1996) proposed that people who experience information poverty: (a) see themselves as devoid of information sources, (b) are on the lower end of some type of class system, (c) engage in defensive behaviors to mitigate the risks of seeking information from potentially hostile or dangerous outsiders, (d) including secrecy and deception, (e) engage in cost-benefit analysis weighing risks of information seeking because they do not fully trust outsiders, and ( $f$ ) this results in selective introduction of new information to the information world.

Although Chatman's work operationalized concepts popular in contemporaneous sociological and critical theory-such as marginalization (Chatman, 1987)-it conformed to the norms of the field at the time by largely side-stepping in-depth, explicit focus on more intractable markers of identity, such as race and disability (Honma,2005). Chatman's theoretical frameworks described (functionally, at least) how marginalization and power imbalances manifested in information behavior but continued to focus primarily on the behavior of the marginalized, rather than on the vehicles of marginalization. Information science research in disability has increased over the past three decades, but much of that work has focused on technology and basic accessibility for people with physical disabilities, rather than examining the underlying social processes by which information marginalization occurs (Hill, 2013). This article attempts to examine some of these more persistent, structural processes.

\section{Phenomenon of Interest and Research Questions Addressed}

This article explores information access, information poverty, and structures of information marginalization among mothers of people with Down syndrome and autism. These two developmental conditions, although different in etiology and presentation, both involve a wide spectrum of neuro-atypicalities and developmental differences (CDC, 2018a, 2018b). People within both groups experience social limitations related to disability, and "good" information has been recognized as critical for these parents (Mackintosh, Myers, \& GoinKochel, 2005). Perhaps because of this, individuals within these groups (in the United States) are, to some degree, represented by national and local community support organizations that 
seek to address information, economic, and political inequities. The following research questions guided the analysis:

- How do participants describe their information practices and information seeking experiences? Could they be described as information poor according to Chatman's theory? What do those descriptions imply for our current understanding of information poverty?

- What contextual factors contribute to defensive information behaviors and knowledge practices described by participants? How can we theorize the relationship between contextual factors and information practices customarily described as indicators of information poverty?

- What are the implications of focusing primarily on improving contextual factors, rather than changing individual or community information practices?

In addition, we propose the concept of information marginalization to describe the institutional and or community-level mechanisms by which information poverty is created.

\section{Disability and Information}

From the perspective of the participants, this study and this are article are not about disability, and this is not an article about health information.

Instead, it is about the everyday life and parenting information needs and practices of people who share a uniting facet of identity (which is, at times, related to health). Because intersections (Crewshaw, 1989) among disability, race, and gender impact everyday information needs and practices (Gibson, Kaplan, \& Vardell, 2017), the information worlds (Jaeger \& Burnett, 2010) and everyday life information needs of mothers of people with disabilities often differ somewhat from those of other mothers (Walker, 2009).

Parents of individuals with disabilities often require specialized information about what might otherwise be considered everyday life and parenting, including expectations for developmental milestones, supporting healthy social interactions, education, and healthcare (Pifalo, Hollander, Henderson, DeSalvo, \& Gill, 1997). For parents of individuals with autism and Down syndrome specifically, access to high-quality information is crucial for navigating complex bureaucratic systems that help them find and manage information related to health and everyday well-being. Health insurance, school systems (e.g., development of Individualized Education Programs ${ }^{11}$ [IEPs]), and government social services all represent labyrinthine systems of information that parents must navigate. Because many of the services they access are local, connection with community is particularly important for parents of children with disabilities (King et al., 2006). Their information needs also change as children age into adulthood. This broad, but specific set of information needs differentiates them from other groups of parents or caretakers (such as those of children with acute illnesses).

\footnotetext{
${ }^{1}$ In the U.S. public education system, Individualized Education Programs (or Plans) are written plans intended to document disabilities that affect a child's learning, annual academic goals, and plans for meeting academic goals in accordance with the needs of the child (including modifications to the general curriculum and pedagogy, alternate assessments and assistive technology needs) and federal and state law. In most cases, IEPs are written by a team that includes the child (if older than 13 years), the child's parents, teachers (general and special education), therapists, and special education administrators (Individuals With Disabilities Education Act, 2004).
} 


\section{Epistemological and Theoretical Stance}

This article is embedded in a critical disability model, which means that we approach disability as comprising individual differences (and, at times, impairments), as well as a range of socially constructed barriers (Corker, 1999; Oliver, 2013). This critical approach informs explicit examination of how unexamined power and privilege contribute to information marginalizationor the development of systemic, contextual barriers to information access. As this study comes from a critical, constructivist grounded theory perspective, we acknowledge that we ourselves (as researchers, educators, and, in the case of the first author, as the mother of a child with a disability) are positioned within the social contexts described in this article. From the interview through the data analysis process, we acknowledge the research as being co-constructed between the researchers and the participants (Charmaz, 2014).

We simultaneously acknowledge the existence of varied challenges and "impairments" related to disability (and accept that a variety of individually-focused interventions can help to improve experience related to those challenges) while also acknowledging that much of what is broadly understood to be "disability" is the outcome of structural inequity, and lack of accommodation for natural variations in human genetics and culture. This critical approach requires that we explicitly examine those inequities, and the way that information systems (both technical and human) similarly include and constitute mechanisms of inclusion, exclusion, and marginalization that create information access and poverty.

Language and Terminology

Debates around terminology—such as whether to use the term "disability," or the usefulness of people first language-are ongoing, even amongst people with disabilities. We have a duty to be reflexive in our discussion of the study design, language choice, findings and implications. We use the term "disability" with the knowledge that its use is contested, because it was used regularly by the participants, and because many self-advocates have embraced "disability" as a descriptor of a collective political and social identity that facilitates shared self-determination and political action (Putnam, 2005; Scotch, 2000). Because we are reflecting the general language usage of the study participants (who are mothers of people with disabilities, and not people with disabilities themselves), we refer to individuals using people first language (e.g., "person with Down syndrome") and the community using identity first language (e.g., "the autistic/autism community"), despite the rising trend in identity-first preferences among autistic adults (Dunn \& Andrews, 2015).

\section{Defining Information Poverty}

In her earliest work on information poverty, Chatman (1987) focused on the information worlds of janitors. The participants and the context of these studies - at a large research university in the Southern United States-described an economic and social power differential that became an underlying feature in information poverty research. Although the development of information poverty as a concept has progressed over time since its initial introduction in the 1960s (Haider \& Bawden, 2007; Yu, 2006), it has largely continued as a cultural deficit model that has measured the information practices and processes of those deemed information poor against institutionalized cultural standards that reflect the values of "white, male, middle-class, heterosexual, U.S.-based" (Noble, Austin, Sweeney, McKeever, \& Sullivan, 2014) people. As a result, the study of information poverty has largely been the study of culturally encoded shortcomings, and (mostly) benevolent technological determinism. 
Assumptions about socio-economic status (SES), class, and "cultures of poverty" have long characterized research on information poverty in LIS. Prior to Chatman, Childers and Post (1975) acknowledged the contextual nature of disadvantage, but still provided a fairly essentialist description of the information poor as shrouded in darkness, "locked into their own subcultures...harboring an inordinate amount of unawareness and misinformation" (p. 32). Chatman explored the social aspects of information poverty, commenting on connections between limited social and information networks and economic poverty (Chatman \& Pendleton, 1995). Solomon (1997) corroborated Chatman's earlier findings, proposing that people who were information poor avoided interactions which might help them and subsequently "selfconstructed" their own information poverty. In blaming individuals and communities for their own information poverty, this approach stymies our ability to understand the underlying structural inequalities that deny them agency. Chatman (1999) began to remedy this by examining structural inequalities that led to secrecy and deception among "information poor" prisoners acting to protect themselves and preserve what little advantage they had over fellow inmates.

Development of the theory has largely been limited by this history of uncritical assumptions about the superiority of institutionally sanctioned information values and equality of power between individuals and the institutions that provide them with information. Haider and Bawden (2007, p. 535) write,

By characterising distinct groups of individuals, organisations or even countries by their perceived lack of information, the underlying assumption has to be that there is a "right kind" as well as a "right amount" of information. It can be argued that existence and nature, as well as position and ideal quantity of this type of information are determined, produced and maintained from a privileged position, by systems of authoritative institutional discourses.

This orientation of privilege extends to disability. This approach to improving information inequality depends on an imbalance of power and an acceptance of institutionally sanctioned information values and ways of knowing, rather than the questioning of the effectiveness and values of institutional information systems. Within this framework, "managerial language" (Wiegand, 1999) is used to frame the "information poor" as having low information processing skills, insufficient experience with bureaucratic systems, insufficient resources (Childers \& Post, 1975; Thompson, 2007), and "poorly developed information infrastructure[s]" (Britz, 2004, p. 192). Rather than focusing on the inflexibility of bureaucratic and information systems that purport to serve these individuals and communities, and questioning the information processes and values inherent in existing information systems, researchers have focused on deficits and problem behaviors (e.g., Goulding, 2001; Sligo \& Jameson, 2000). This narrow focus on individual behaviors, rather than contextual preconditions for those behaviors also frees information science researchers from the obligation to understand how marginalization works. This, in turn, limits our ability to develop information systems (human, and machine) that reflect and respond to the needs of communities at the margins. Although many of these studies have proved useful for highlighting areas of social or moral imperative (e.g., the digital divide or information literacy divides), and describing substantive information needs, they also represent missed opportunities to examine information poverty as a mismatch between the embedded epistemologies of the information seeker and the information system.

Hasler and Ruthven (2011), Lingel and Boyd (2013), and Greyson (2017) depart from this tradition, focusing, respectively, on the ways that people use secretive information seeking to find information that they deem important, the ways that information poverty can be localized to 
portions of an individual's identity or information world, and how young parents engage in defensive information behaviors. Lingel and Boyd differentiate between two strains of information poverty research-research that focuses on people who "are systematically marginalized in ways that shape access to information" such as those who experience economic poverty or racial discrimination (i.e., visible minorities) and that which focuses on those who simultaneously experience varying levels of privilege based on a temporary or invisible characteristic. This study is complex in this regard, as non-disabled mothers of people with disabilities often experience pervasive discrimination related to their roles as mothers of disabled individuals (as compared to mothers of nondisabled children), but unless they also have a disability, they maintain their own individual privilege (as non-disabled people). When they move through the world alone, they often do not have to manage discrimination that would affect their children - they themselves are not disabled. In this way, they straddle both groups described by Lingel and Boyd-systematically marginalized, but also experiencing varying levels of personal privilege.

\section{Methods}

A purposive, theoretically driven sample of 24 mothers of individuals with either Down syndrome or Autism participated in in-depth, semi-structured interviews about their information seeking experiences related to seeking information about raising their children. A theoretically driven sample uses theoretical saturation-full development of concepts or theory- as the prime motivator for sample size (Charmaz, 2014).

The study sample included mothers of individuals with Down syndrome and an Autism Spectrum Disorder (ASD) from five U.S. states (Florida, North Carolina, Georgia, California and Texas). Participants ranged from 30-46 years of age and their children ranged in age from 2-26 years old. In terms of racial diversity, the sample included white $(n=10)$, African-American $(n=$ $8)$, Latinx/Hispanic $(n=6)$ mothers. We did not collect data about family income.

Interviews took place between August 2014 and September 2016 and were based on Sonnenwald, Wildemuth, and Harmon's (2001) Information Horizons protocol, which is designed to prompt participants to describe arange of information seeking experiences. Participants were recruited through combination of purposive sampling (using emails distributed by local parent groups) and snow-ball sampling. Participants selected locations for interviews. Each participant was given a \$25 incentive. Interviews were audio recorded and lasted between 30 and 70 minutes. The first author conducted all interviews and conducted member checks with participants after transcription. Interviews were audio recorded, transcribed by the interviewer and a research assistant and coded by the interviewer and the second author using NVIVO software. Researchers coded each set of interviews over a 6-week period in separate, duplicate versions of the dataset, meeting weekly to compare codes, discuss emergent concepts, and resolve coding disagreements through discussion.

\section{Analysis and Theoretical Development}

This study occurs within the context of a larger arch of constructivist grounded theory research, and follows similar exploratory studies of information practices of parents of people with disabilities (for further work, see Gibson, 2014; Gibson et al., 2017). We do not approach the study as tabula rasa, but built on previous grounded theory work (Gibson, 2014), combining standard thematic analysis with the constant comparative method of theoretical development used in constructivist grounded theory research (Charmaz, 2014; Kolb, 2012). We analyzed data inductively, using Chatman's (1996) theory of information poverty as sensitizing theory for 
initial open coding and memoing (Charmaz, 2003). Subsequent coding focused identification of defensive, proactive, or coping behaviors and contextual factors that contributed to those behaviors. Table 1 frames the participants' experiences as a series of behaviors and conditions reflective of Chatman's propositions. As is common with grounded theory work, the resulting product comprises both empirical and theoretical findings.

\section{Results}

The following sections (and associated tables) describe marginalization factors, individual and community-level parent information and knowledge practices (including defensive behaviors parents engaged in response to marginalization factors) and give examples from the data. Because the data presents institutional behaviors and information seeking contexts from the parent perspective, and it is difficult, at times, to draw lines between institutional behavior and the information-seeking contexts those behaviors creates for parents, we have collapsed them into a single category that encompasses both, called information marginalization factors.

Finally, emotional, affective, and knowledge states that parents were aware enough to name are included here among knowledge practices. In several cases, the line between conscious affective states (such as "being angry") and passive information behavior (such as "waiting" for information) was too difficult to draw, so both are included.

The following four sections: Perceived Information Deficits, Class Distinctions, Risk Assessment/Selective Introduction of Information, and Secrecy: Risk Assessment and Conflict Avoidance map neatly to Chatman's (1996) propositions 1, 2, 4, 5, and 6 (see introduction for Chatman's propositions). Proposition 3 , which posits that people who are information poor engage in a range of defensive information behaviors, is observable in all four of the following sections. Each section is organized by information marginalization factors. In many cases, situations and behaviors described occupy can more than one table, but they are placed in the table that most embodies the theme in the text.

\begin{tabular}{|c|c|c|c|c|}
\hline \multicolumn{2}{|c|}{$\begin{array}{l}\text { Information } \\
\text { marginalization } \\
\text { factors } \\
\text { (institutional } \\
\text { action/ } \\
\text { contextual } \\
\text { conditions) }\end{array}$} & $\begin{array}{l}\text { Individual knowledge } \\
\text { practices/defensive } \\
\text { behaviors }\end{array}$ & $\begin{array}{l}\text { Community-level } \\
\text { practices/ } \\
\text { defensive behaviors }\end{array}$ & Sample Data \\
\hline 1 & $\begin{array}{l}\text { Lack of } \\
\text { trustworthy, } \\
\text { locally- } \\
\text { relevant } \\
\text { information } \\
\text { sources }\end{array}$ & $\begin{array}{l}\text { Seeking local } \\
\text { information }\end{array}$ & $\begin{array}{l}\text { Facebook group } \\
\text { development \& growth/ } \\
\text { social media } \\
\text { participation } \\
\text { Pooling/Sharing } \\
\text { information in groups via } \\
\text { meetings, email, etc. }\end{array}$ & $\begin{array}{l}\text { "Information wise, I } \\
\text { would say that it is } \\
\text { more local, that I am } \\
\text { not looking } \\
\text { nationally. Like I'm } \\
\text { not looking at the } \\
\text { national level." }\end{array}$ \\
\hline 2 & & $\begin{array}{l}\text { Seeking information } \\
\text { from other parents } \\
\text { (rather that } \\
\text { professionals/providers) } \\
\text { Seeking information } \\
\text { outside of } \\
\text { local community }\end{array}$ & $\begin{array}{l}\text { Information seeking and } \\
\text { distribution by } \\
\text { organizations }\end{array}$ & $\begin{array}{l}\text { "I'm in this Facebook } \\
\text { group, support for } \\
\text { parents...And we are } \\
\text { all on Facebook from } \\
\text { all over the US and } \\
\text { some people from } \\
\text { Europe and Australia, }\end{array}$ \\
\hline
\end{tabular}




\begin{tabular}{|c|c|c|c|c|}
\hline & & & & $\begin{array}{l}\text { so there is a lot of } \\
\text { moms, that they are } \\
\text { all the time, up to } \\
\text { date, with really new } \\
\text { stuff." }\end{array}$ \\
\hline 3 & $\begin{array}{l}\text { Perception } \\
\text { of } \\
\text { information } \\
\text { being } \\
\text { withheld }\end{array}$ & $\begin{array}{l}\text { Seeking information } \\
\text { from community } \\
\text { groups/ } \\
\text { nonprofits }\end{array}$ & $\begin{array}{l}\text { Collaboration between } \\
\text { parent } \\
\text { community/organizations }\end{array}$ & $\begin{array}{l}\text { "They [community } \\
\text { organization outside } \\
\text { of school system] } \\
\text { actually offered a } \\
\text { transition to preschool } \\
\text { thing and then they } \\
\text { offered a IEP } 101 \text { and } \\
\text { it was a good } \\
\text { seminar, because it } \\
\text { was like } \\
\text { 'this is what the IEP } \\
\text { looks like." }\end{array}$ \\
\hline 4 & & $\begin{array}{l}\text { Persistent questioning/ } \\
\text { Information seeking as } \\
\text { Resistance } \\
\text { Fighting } \\
\text { / Advocating }\end{array}$ & $\begin{array}{l}\text { Legal/administrative } \\
\text { action to } \\
\text { ensure information } \\
\text { distribution within } \\
\text { communities. } \\
\text { Assuming collective/ } \\
\text { community stance of } \\
\text { advocacy }\end{array}$ & $\begin{array}{l}\text { "I called the head of } \\
\text { everything" } \\
\text { "They're like, you got } \\
\text { to fight for your kid, } \\
\text { you got to fight for } \\
\text { your kid this that, and } \\
\text { the other and l'm like } \\
\text { okay but, it just } \\
\text { seems standard." }\end{array}$ \\
\hline 5 & & $\begin{array}{l}\text { Being intentionally } \\
\text { visible and } \\
\text { present. } \\
\text { non-disability } \\
\text { community } \\
\text { Building strategic } \\
\text { professional } \\
\text { relationships }\end{array}$ & $\begin{array}{l}\text { Encouraging visibility \& } \\
\text { active participation in } \\
\text { local } \\
\text { non-disability community }\end{array}$ & $\begin{array}{l}\text { l've become known at } \\
\text { 's school...I } \\
\text { volunteer enough that } \\
\text { the teachers know me } \\
\text { and I've become } \\
\text { somewhat friendly } \\
\text { with the EC liaison so } \\
\text { l've been able to use } \\
\text { her as a resource to } \\
\text { get some information } \\
\text { about what I need to } \\
\text { be doing in order to } \\
\text { make sure __ gets } \\
\text { the } \\
\text { spot. }\end{array}$ \\
\hline 6 & $\begin{array}{l}\text { Lack of } \\
\text { information } \\
\text { about } \\
\text { rights }\end{array}$ & $\begin{array}{l}\text { Joining parent group to } \\
\text { learn about disability } \\
\text { rights }\end{array}$ & $\begin{array}{l}\text { Formal/Informal } \\
\text { community } \\
\text { building/information } \\
\text { network expansion/ } \\
\text { organizational advocacy } \\
\text { work }\end{array}$ & $\begin{array}{l}\text { I was very, very } \\
\text { involved with the } \\
\text { autistic community, } \\
\text { with other parents, } \\
\text { and when I mean } \\
\text { other parents, these } \\
\text { are motivated }\end{array}$ \\
\hline
\end{tabular}




\begin{tabular}{|l|l|l|}
\hline & & $\begin{array}{l}\text { parents... These are } \\
\text { parents who are very } \\
\text { proactive, who know } \\
\text { a thing or two about } \\
\text { autism, know a thing } \\
\text { or two about services, } \\
\text { know a thing or two } \\
\text { about our rights. }\end{array}$ \\
& \\
& \\
\hline
\end{tabular}

\section{Perceived Information Deficits}

Table 1 describes contextual conditions related to perceived information deficits evident in the data, and individual and community information practices that constituted participant responses to these conditions.

For the most part, mothers were satisfied with the amount and quality of basic information about their children's disabilities given to them by health professionals and found on the Internet. This type of information included basic medical, social, and developmental information about Down syndrome and autism, commonly associated conditions, general information about co-occurring conditions, and possible complications. This type of information straddled the line between orienting and practical (Savolainen, 1995), orienting mothers to a range of norms of life with a child with a disability, helping them to form expectations and plan for the future, and avoid (or quickly resolve) problems. Mothers usually sought this type information just prior to, and at the beginning of transitions (e.g., at diagnosis/birth, when a child enrolled in school, or at the beginning of puberty).

\section{Lack of trustworthy local information sources.}

Those who were unhappy with the quality or availability of this type of information mostly described themselves and their communities as devoid of consistently trustworthy information sources, rather than as devoid of any information at all. Locally-oriented and transactional information about daily life in the local community was more difficult to find. This type of information included referrals, resources for locating and using services (e.g., how to find medical care or therapy, register for school, or successful strategies for engaging in the IEP process at a local school), and information provided as services. An example of the latter included therapies (when parents were given interventions to administer at home), potty training services, medical diagnoses and educational assessments. Parents attempted to remedy this by creating their own trusted information networks, whenever possible.

\section{Information withheld and lack of information about rights.}

Although parents described many trusting relationships with practitioners and service providers, many also described situations in which their children suffered because valuable information had been withheld (sometimes intentionally, parents thought) by gatekeepers. These gatekeepers functioned as "obligatory points of passage" (Star \& Griesemer, 1989) between parent and the provider's professional domains (e.g., doctors, therapists, or teachers). Parents needed to work with gatekeepers, but the consequences for lost, forgotten, or withheld information fell on the parent and child rather than the service provider. Frequently, this information related to children's or parents' civil rights. 
Defensive behaviors developed in response to this included proactive and persistent information seeking and embracing an epistemological stance of information seeking as an act of resistance against a "broken system." As one mother said, "sometimes you have to be that mom."

Many of these more confrontational perspectives on information seeking originated with the perception that information related to the child's civil rights was withheld.

\section{Community building.}

Most participants explicitly acknowledged the value of a strong support community. Exact definitions of "community" differed, and participants' perceptions of the structure and purpose of their local and online support communities varied. Most acknowledged community as a vehicle for sharing resources.

\section{Class Distinctions}

Table 2 describes contextual conditions related to class distinctions evident in the data, and individual and community information practices that constituted participant responses to these conditions.

For the purposes of this study, we employ a broad definition of class as a system of relationships embodying inherent social or economic inequalities (Krieger, Williams, \& Moss, 1997). Class distinctions, which indicate positioning within a social, economic, or political community, implicitly indicate inequality in social and political power and can point to either open bigotry or systemic marginalization of certain groups. In the same way that individuals do not have class in and of themselves (class is relational), class distinctions are inherently statements about community structure and values.

Equally evident in the data were class distinctions between nondisabled and disabled people, and among groups of people with disabilities. Barriers associated with race, ethnicity, language, education, and income level and intersected with child's disability status to impede information seeking and access.

\section{Ableism}

Mothers described several instances of discrimination by nondisabled people and organizations. Several bordered on illegal denial of legally guaranteed rights. Some examples of these were children being denied access to services, programming, and public spaces, and lack of planning for adults with disabilities (in terms of accessibility and reading level of information provided for otherwise independent adults with disabilities). Here, we found that parents frequently described states of being as information behaviors that reflected a lack of structural and power. For example, they described waiting for information, expressing disappointment as a means of shaming or guilting others into disclosing information.

\section{Information Literacy and Parent Education}

Low levels of accessibility, low comprehensibility, and low readability of information sources was a huge issue for mothers concerned about navigating information systems (machine and human). Several parents cited advanced education and insider knowledge gained through their careers as key to comprehending health and education-related information, understanding social norms for managing information gatekeepers, accessing medical research, and making quality judgments. 


\begin{tabular}{|c|c|c|c|c|}
\hline \multicolumn{2}{|c|}{$\begin{array}{l}\text { Information } \\
\text { marginalization factors } \\
\text { (institutional action/ } \\
\text { contextual conditions) }\end{array}$} & $\begin{array}{l}\text { Individual } \\
\text { knowledge } \\
\text { practices/defensive } \\
\text { behaviors }\end{array}$ & $\begin{array}{l}\text { Community-level } \\
\text { practices/ } \\
\text { defensive } \\
\text { behaviors }\end{array}$ & Sample Data \\
\hline 1 & $\begin{array}{l}\text { Ableism: Denial of } \\
\text { access }\end{array}$ & $\begin{array}{l}\text { Waiting } \\
\text { Hoping } \\
\text { Expressing } \\
\text { disappointment/ } \\
\text { anger }\end{array}$ & & $\begin{array}{l}\text { I had [heard] all these } \\
\text { positive experiences } \\
\text { from all these other } \\
\text { moms, and at the end of } \\
\text { the summer I was } \\
\text { basically told, } \\
\text { "We don't have a spot for } \\
\text {." I was first crushed, } \\
\text { and second, then, "why } \\
\text { the hell did you tell me } \\
\text { okay at the beginning?" } \\
\text { Because that's, I was } \\
\text { really mad. Still mad. But } \\
\text { she's like, } \\
\text { "Do you understand?" } \\
\text { I'm like, "Oh I clearly } \\
\text { understand what you're } \\
\text { saying." }\end{array}$ \\
\hline 2 & $\begin{array}{l}\text { Information } \\
\text { Literacy/ } \\
\text { Parent Education: } \\
\text { Lack of readable, } \\
\text { accessible } \\
\text { information. } \\
\text { Access requires } \\
\text { high levels of } \\
\text { education/ industry } \\
\text { "insider" } \\
\text { knowledge. }\end{array}$ & $\begin{array}{l}\text { Relying on } \\
\text { individual } \\
\text { education to inform } \\
\text { decision-making. } \\
\text { Making judgements } \\
\text { about personal } \\
\text { information literacy } \\
\text { relative to other } \\
\text { parents. }\end{array}$ & $\begin{array}{l}\text { Variations in } \\
\text { access to, and } \\
\text { accessibility of, } \\
\text { information }\end{array}$ & $\begin{array}{l}\text { I'm a lawyer though, so } \\
\text { I'm used to reading high } \\
\text { volumes of material so it } \\
\text { wouldn't necessarily affect } \\
\text { me the way it would other } \\
\text { people. } \\
\text { I'm a trained journalist, so } \\
\text { I search out too much } \\
\text { information and then you } \\
\text { don't know what to do with } \\
\text { it. } \\
\text { You know one of the } \\
\text { benefits, I work in } \\
\text { the healthcare } \\
\text { industry...Coming into it, I } \\
\text { had a good sense of like - } \\
\text { I know crazy when I hear } \\
\text { it, which is fortunate, } \\
\text { because there's a lot of } \\
\text { crazy information out } \\
\text { there on the Internet about } \\
\text { Autism, and I fear you } \\
\text { know, for people who } \\
\text { don't know better, it }\end{array}$ \\
\hline
\end{tabular}




\begin{tabular}{|c|c|c|c|c|}
\hline & & & & $\begin{array}{l}\text { concerns me what people } \\
\text { are willing to } \\
\text { believe. }\end{array}$ \\
\hline 3 & $\begin{array}{l}\text { Income inequality: } \\
\text { Time \& Money } \\
\text { Lack of access to } \\
\text { information } \\
\text { through expected } \\
\text { institutions } \\
\text { Inequities in access } \\
\text { to insurance }\end{array}$ & $\begin{array}{l}\text { Not knowing how to } \\
\text { pay for medical } \\
\text { care and therapy } \\
\text { services } \\
\text { Hiring private } \\
\text { consultants to } \\
\text { provide } \\
\text { information/services }\end{array}$ & $\begin{array}{l}\text { Pooling } \\
\text { financial } \\
\text { resources to } \\
\text { access } \\
\text { information } \\
\text { through } \\
\text { consultants } \\
\text { (through support } \\
\text { organizations or } \\
\text { groups of } \\
\text { parents). }\end{array}$ & $\begin{array}{l}\text { Applied Behavioral } \\
\text { Analysis...she used to } \\
\text { get ABA services years } \\
\text { ago but then } \\
\text { money just wasn't } \\
\text { available for me to pay a } \\
\text { therapist, because they } \\
\text { get paid approximately } \\
\$ 150 \text { an hour and } \\
\text { insurance doesn't cover } \\
\text { that. } \\
\text { I just had an IEP update } \\
\text { from 's school, and I } \\
\text { feel his goals are too } \\
\text { easy...So we're going to } \\
\text { actually schedule another } \\
\text { meeting, but in that } \\
\text { meeting l'm } \\
\text { bringing his program } \\
\text { director from the } \\
\text { ABA company because I } \\
\text { feel like she is the } \\
\text { specialist in this area and } \\
\text { she's the } \\
\text { best one to provide } \\
\text { advice, you know? }\end{array}$ \\
\hline 4 & $\begin{array}{l}\text { Racial inequity: } \\
\text { Lack of } \\
\text { diversity/systemic } \\
\text { racism }\end{array}$ & $\begin{array}{l}\text { Actively seeking } \\
\text { racially diverse } \\
\text { settings. }\end{array}$ & & $\begin{array}{l}\text { We were coming from } \\
\text {...lots of diversity, so my } \\
\text { son's best friend in } \\
\text { Montessori was a little } \\
\text { Nigerian boy...his other } \\
\text { really good friend...his } \\
\text { mom } \\
\text { was Mexican, his father } \\
\text { was Black and } \\
\text { French... anyway very } \\
\text { diverse. Just a great } \\
\text { school. So to go from that } \\
\text { to all-White, we were like } \\
\text { that's not going to work... } \\
\text { just didn't want him to be } \\
\text { bullied, I didn't want any } \\
\text { bad experiences, I'm just } \\
\text { trying to head it off. }\end{array}$ \\
\hline
\end{tabular}


Time and money were described as scarce (and valuable) resources that influenced parents' ability to participate socially in the world of the parent support group, and to dedicate attention to additional medical or educational needs. Many of the defensive information behaviors described in this paper (e.g., second opinions, consultation with outside experts, etc.) required time and financial resources, and in some cases, the ability to pay for services relied on parents knowing or not knowing how to access insurance or financial support. Because several participants talked at length about "not knowing" as a liminal state (sometimes an intentional choice, sometimes involuntary, but frequently palpable), it is described here as a knowledge practice. In some cases, parents who knew (or "made it their business to know") about managing or procuring financial resources also enjoyed a type of increased status among other parents. In addition to health insurance access, insurance literacy-the ability to understand insurance regulations (particularly approvals, denials, and billing), and knowledge about government-sponsored insurance and supplementary income were valued.

\section{Racial Inequities}

Other mothers openly discussed race, ethnicity, and dis- ability as intersections of identity (Crewshaw, 1989) that each carried an additional level of externally imposed burden and risk with regards to information seeking. When mothers of color talked about information seeking within White spaces, they were doubly concerned about racism and ableism they and their children might encounter from other children, parents, and school administrators. In discussing her frustration with IEP with her son's school, one mother decried what she characterized as "disability fatalism coupled with racialized black boy fatalism" - a belief that her son could not learn. In this mother's view, this devaluing of her son gave school administrators license to withhold, neglect, and misrepresent information and educational data. Despite her living in what she called "one of the best public-school districts in the state," she had to spend her own money and time to hire a special education advocate to find information that should have been provided by her school district.

\section{Situational Relevance Assessments: Inadequate Support for Subgroups}

Table 3 describes situational relevance assessments and individual and community information practices that constituted participant responses to these conditions. This theme was particularly strong, with parents citing inadequate support for age, racial, and gender subgroups. Among these, the most frequently cited subgrouping was child age. Parents with children of different ages needed different types of information and would often build communities with other parents of children their child's age to meet information needs. Similarly, parents of Black and Latinx children bemoaned the lack of support for their culturally-specific information needs.

\begin{tabular}{|l|l|l|l|}
\hline TABLE 3. Situational Relevance Assessment \\
\hline Information & Individual knowledge & Community- & Sample Data \\
marginalization factors & practices/ & level \\
(institutional & defensive behaviors & $\begin{array}{l}\text { practice/ } \\
\text { defensive } \\
\text { behaviors }\end{array}$ & \\
action/contextual & & & \\
conditions) & & & \\
\hline
\end{tabular}




\begin{tabular}{|c|c|c|c|c|}
\hline 1 & $\begin{array}{l}\text { Inadequate } \\
\text { support for } \\
\text { subgroups. }\end{array}$ & $\begin{array}{l}\text { Community building: } \\
\text { Choosing } \\
\text { friends and support } \\
\text { group based on } \\
\text { relevance (grouping } \\
\text { by child } \\
\text { age). }\end{array}$ & $\begin{array}{l}\text { Development } \\
\text { of cliques } \\
\text { and } \\
\text { micro- } \\
\text { communities }\end{array}$ & $\begin{array}{l}\text { We have...different groups } \\
\text { based on the year your son } \\
\text { was born, so my son is the } \\
2014 \text { moms with kids } \\
\text { rocking the extra } \\
\text { chromosome. } \\
\text { We have a support group } \\
\text { in, it's kind of based on age, } \\
\text { so l'll go to the younger } \\
\text { children's support group } \\
\text { from time to time and I will } \\
\text { talk to them in } \\
\text { person...Because I } \\
\text { feel like it's important you } \\
\text { know? } \\
\text { You need to get a support } \\
\text { system...I can tell you I } \\
\text { found it through } \\
\text { meetup.com. }\end{array}$ \\
\hline
\end{tabular}

\section{Risk Assessment/Selective Introduction of Information}

Table 4 describes situational risk assessment and selective introduction of information sources, and the individual and community information practices that constituted participant responses to these conditions.

Parents engaged in a variety of information behaviors to protect themselves from perceived threats in their information worlds and to increase their agency as they interacted with others in the information world. Threats included direct threats to the wellbeing of their children, such as bullying in the classroom, lack of proper treatment or medical care, or exacerbation of developmental delays; and threats to parents' ability to find information, such as the withholding of information by gatekeepers, unfruitful expenditure of scarce resources (e.g., time or money), undesired emotional and psychological states (e.g., frustration, depression), and reduced ability and autonomy in decision-making. Two of the most frequently mentioned tactics for managing this contextual condition were secrecy (or selective information sharing), and community building.

\begin{tabular}{|c|c|c|c|c|}
\hline \multicolumn{2}{|c|}{$\begin{array}{l}\text { Information } \\
\text { marginalization } \\
\text { factors } \\
\text { (institutional } \\
\text { action/ } \\
\text { contextual } \\
\text { conditions) }\end{array}$} & $\begin{array}{l}\text { Individual } \\
\text { knowledge } \\
\text { practices/defensive } \\
\text { behaviors }\end{array}$ & $\begin{array}{l}\text { Community- } \\
\text { level } \\
\text { practices/ } \\
\text { defensive } \\
\text { behaviors }\end{array}$ & Sample data \\
\hline 1 & $\begin{array}{l}\text { Overload of } \\
\text { mixed- } \\
\text { quality } \\
\text { information }\end{array}$ & $\begin{array}{l}\text { Experiencing } \\
\text { information } \\
\text { overload }\end{array}$ & $\begin{array}{l}\text { Person to } \\
\text { person } \\
\text { information }\end{array}$ & $\begin{array}{l}\text { And I hate the internet anyway, } \\
\text { so like let's say you Googled } \\
\text { whatever that }\end{array}$ \\
\hline
\end{tabular}




\begin{tabular}{|c|c|c|c|c|}
\hline & & & $\begin{array}{l}\text { sharing as } \\
\text { social norm }\end{array}$ & $\begin{array}{l}\text { everybody's been giving their } \\
\text { kids...you'll get a } 1000 \text { different } \\
\text { sites with godly unknown pages } \\
\text { upon pages, that's information } \\
\text { overload, you know?...it's not } \\
\text { worth it... } \\
\text { forget it. l'd rather spend five } \\
\text { seconds asking somebody than } \\
\text { five hours trying to search } \\
\text { through all that. }\end{array}$ \\
\hline 2 & $\begin{array}{l}\text { Abuse: } \\
\text { Disregardin } \\
\mathrm{g} \\
\text { parent/child } \\
\text { agency and } \\
\text { well-being }\end{array}$ & $\begin{array}{l}\text { Employing secret } \\
\text { rubric for authority } \\
\text { assessment } \\
\text { (secrecy) }\end{array}$ & & $\begin{array}{l}\text { They told us...if it went that way } \\
\text { the next time they were going to } \\
\text { have to restrain him, essentially } \\
\text { put him in a straightjacket...I had } \\
\text { a big problem with the idea of } \\
\text { them putting a kid in a restraint } \\
\text { like that. So I decided not to go } \\
\text { back to them, so that's what I've } \\
\text { been looking for essentially, } \\
\text { when I call...these dentists - just } \\
\text { to make sure that they're not } \\
\text { going to want to resort to that } \\
\text { kind of treatment. }\end{array}$ \\
\hline 3 & $\begin{array}{l}\text { Professional } \\
\text { Neglect }\end{array}$ & $\begin{array}{l}\text { Hesitating to seek } \\
\text { information from } \\
\text { institution } \\
\text { Feeling bullied }\end{array}$ & & $\begin{array}{l}\text { We started the evaluation } \\
\text { process through_...At this point } \\
\text { he was just turning three, we } \\
\text { were told that he needed to go } \\
\text { to public school and we didn't, I } \\
\text { just felt like we didn't get good } \\
\text { answers about why that was } \\
\text { necessary. He was already going } \\
\text { to be in church preschool at } \\
\text { three, and they just really, I don't } \\
\text { want to use the word bullied, but } \\
\text { that's how I felt, I almost felt I } \\
\text { was bullied into putting him } \\
\text { there without a really good } \\
\text { explanation of why that was } \\
\text { necessary. }\end{array}$ \\
\hline
\end{tabular}

\section{Overload}

Participants experienced information overload most frequently during transitions. Transitions (e.g., diagnosis, enrolling in school for the first time, puberty, or transition to adulthood) often brought with them a marked increase in emotional vulnerability, and a need for information to support decision-making. For parents in this position, having to judge the quality of large amounts of information was overwhelming. The emotional and cognitive effort involved in judging between good and bad information and advice caused some parents to feel overwhelmed. One mother described her ideal situation as follows: 
I should probably mention the number one resource that's been helpful...they're a nonprofit kind of a like an advocacy group where we were assigned a case manager. And our case manager really walked us through the different resources that were available and getting us services and he helped us transition on to the school system. That was probably the most helpful resource throughout our entire process. So he helped me...understand all the different paperwork, all the different meetings, all the different evaluations and whatnot that had to be done to get my son into school.

Several participants expressed a preference for individual guidance from trusted authorities (usually from trusted organizations) who could help them identify their specific information needs, manage information seeking and organizational processes, and plan a course of action.

\section{Abuse and Neglect}

Participants described many versions of defensive secrecy to screen for (and guard against) indicators of potential abuse, or professional neglect. They tested for what they perceived to be an appropriate level of knowledge, acceptable beliefs, and behaviors. For example, a parent's early conversations with a pediatrician might involve subtle tests of a doctor's knowledge about (or attitudes about) ASD. Many parents decided very quickly whether a given provider's approach to treatment aligned with their own values. Rather than risk conflict once the provider was in a position of power, these parents used these early conversations to make judgments about providers' positions on key concerns (such as vaccinations or therapy), or experience treating other children with their child's disability. Sometimes these examinations were imperceptible to the provider and included observations about correct language usage (e.g., use of people first language, or the parent's preferred usage of "person with Autism" versus "Autistic person"). Sometimes they were more explicit. For some mothers of young or newly diagnosed children, state-assigned or state-funded caseworkers, teachers, and practitioners represented the power of the state or local school board to make decisions about their children's care. These institutions had the power to override parental autonomy and agency, and, for a few mothers, presented a particular risk. For many parents, avoiding conflict with a provider was preferable to the risk involved in direct confrontation, but this sometimes meant disengaging from a valuable source of needed information.

\section{Trust and risk assessments.}

Trust was central to parents' information seeking. Trust in veracity and currency of information found online was a concern for parents seeking information online. Trust in privacy policies (at Facebook and Google) and trust in the maintenance of confidentiality among group participants (and to some extent, the anonymity of the internet) freed parents to share extremely personal information with others via social media. For many participants, trust was a prerequisite for developing ongoing relationships with service providers and was not given easily (the perceived risk of failure was too costly). Trust based on shared experience (and cognitive authority) was the social capital that enabled parent support groups to function effectively as mechanisms for referral and legitimation. Trust among parents and professionals was often low. When participants mistrusted the intentions or priorities of their service providers, they often did not trust the information itself, rendering it "theoretically close, but inaccessible in practice" (Mervyn \& Allen, 2012, p. 1128).

\section{Discussion}




\section{Resituating Information Poverty}

As currently used, the term information poor acts an essentialist label, used to describe deficits in groups and individuals. Resituating the concept of information poverty, and re-conceptualizing it as an array of self-protective responses to information marginalization refocuses blame away from individuals experiencing marginalization, and toward the contextual conditions that create information poverty. This shift in focus is more than "political correctness." The data demonstrated that mothers exhibited a range of defensive behaviors and practices commonly associated with information poverty in response to persistent structural problems (contextual conditions) in face-to-face information environments and online information systems. The mothers engaged in information sharing and (sometimes subversive) information seeking because they often found information hard to gather as individuals and gauged the risks of trusting institutional sources to be too high. They used secrecy as self-protective behavior, sought advice and referrals from other parents, and used social media for social support. This did not always result in the exchange of high-quality information, and in some cases, led to lessthan-optimal outcomes for their children. Although some time, energy, and resources should clearly be dedicated to ensuring that these mothers have the information seeking and literacy skills to successfully find desired information and make quality judgments, equal, if not more, emphasis should be placed on ensuring that the information systems they use are intentionally and thoughtfully designed so that they do not prompt mothers to engage in defensive information practices in the first place. Recognizing "information poverty-related behaviors" as red-flags-signals that there is a design flaw or mismatch between the parameters of the system and the needs of the user-is a first step in resolving this problem.

\section{Limits of Subcultural Limitation}

Chatman (1996) writes that only insiders can understand the information worlds of other insiders characterizing "the information poor" as a relatively fixed class that experiences subcultural limitation (living in a closed society, without knowledge about the social norms of those with power). Despite the historical framing of information poverty as a deficit that limited the individuals' ability to perceive the broader world around him or her, we found that mothers who were often fully aware of (and many times, resentful of) barriers to information imposed upon them. Although it is true that the parents in this study exhibited some information behaviors that might not be considered "mainstream" (Thompson, 2007), they exhibited social information seeking skills that reflected their information needs, information values, and social values. From their perspective, participants saw lack of information as problem with infrastructure, rather than just one of information literacy or access. Parents did not internalize the deficit approach. They largely saw the information systems (rather than themselves) as needing repair. In many cases, they did not have the power to repair them, and resorted to a range of defensive behaviors that ran from extremely passive (e.g., waiting and hoping) to organized and active (e.g., community building).

\section{Situating Information Marginalization}

Several recent works also reflect this shift in focus toward examining the impact of systems, rather than the labeling of individuals as defective. Eubanks (2018) address systemic inequity from the perspective of search engines and automated systems. Noble (2018) introduces the idea of a "technologically redlined" internet, in which segregation is reproduced through uncritical application of ostensibly "colorblind" system development. Hoffmann (2018) makes a particularly poignant argument about data violence, acknowledging the importance of engaging 
information professionals and researchers in broad thinking about ethical design processes. Hoffman writes,

the problem here isn't only one of biased datasets or unfair algorithms and of unintended consequences. It's also indicative of a more persistent problem of researchers actively reproducing ideas that damage vulnerable communities and reinforce current injustices.

Expanding information science research, practice, and education requires a willingness to address social issues, engage in critical inquiry, and to support interdisciplinary thinking. Other works on the consequences of algorithms have explored the moral responsibilities of Facebook, Google, and other technology companies have highlighted how important it is for system developers and designers of all types to understand the ways that information systems can marginalize (Tufekci, 2017).

Likewise, future work on information access and information literacy would benefit from a shift away from deficit-focused models and frameworks to frameworks that acknowledge individual and community knowledge practices, defensive information behaviors affective and passive responses as rational responses to marginalization. It is tempting, and easy, to unquestioningly prioritize the information values (Jaeger \& Burnett, 2010) of institutions (especially our own educational/research institutions), and label those who do not share those values as information poor, lacking agency, or lacking in information literacy (Haider \& Bawden, 2007). It is more difficult to interrogate the values and structures that privilege certain ways of knowing, information seeking, and sharing. If information science is to is supposed to improve information access for all different kinds of people, then researchers cannot shy away from employing critical theoretical lenses that interrogate foundational social structures (i.e., the normative order of social practices and constructs; Giddens, 1984) related to identity, such as race, class, gender, and disability, and not be cowed by what could be the massive implications of our work. If we acknowledge that what we call information poverty is often a result of systemic failure of information systems to meet the needs of marginalized groups of people, we must also acknowledge that the solution lies in the development and improvement of those systems, rather than essentialist statements about those groups of people. This might also demand reassessment of the field's own constructions of relevance, quality, and authority, and centering of a diverse range of information values, rather than imposition of those currently embraced by the field.

\section{Conclusion}

What the field of information has called "information poverty" is driven by social constructions of power and privilege that influence physical, emotional, intellectual, or financial ability to seek, find, and use relevant and high-quality information. The concept of information poverty is limited, in that it only describes one half of a relationship between marginalized individuals or groups and more powerful institutions or social groups. Providing high-quality information services to traditionally marginalized communities requires that information professionals (whether they are building social or technical information systems) understand information poverty and information marginalization as dyadic perspectives on the same mismatch of information values and imbalance of power that often exists between marginalized people and the institutions that purport to serve them. Moving forward, it is important that we examine how those power imbalances are operationalized in different contexts and at different scales, the mechanisms by which marginalization occurs, and the range of typical responses exhibited by people experiencing information marginalization. Only then can we make the changes needed to create equitable information systems that serve diverse communities well. 


\section{References}

Britz, J.J. (2004). To know or not to know: A moral reflection on information poverty. Journal of Information Science, 30(3), 192-204.

CDC. (2018a). Down syndrome: Birth defects. NCBDDD \& CDC. Retrieved from https://www.cdc.gov/ncbddd/birthdefects/downsyndrome.htmICDC. (2018b). Basics about autism spectrum disorder (ASD). NCBDDD \&CDC. Retrieved from https://www.cdc.gov/ncbddd/autism/facts.html

Charmaz, K. (2003). Grounded theory methods in social justice research. In N. Denzin \& Y. Lincoln (Eds.), Strategies of qualitative inquiry (pp.249-291). Thousand Oaks, CA: Sage.

Charmaz, K. (2014). Constructing grounded theory. Thousand Oaks, CA: Sage.

Chatman, E.A. (1987). The information world of low-skilled workers. Library and Information Science Research, 9(4), 265-283.

Chatman, E.A. (1996). The impoverished life-world of outsiders. Journal of the American Society for Information Science, 47(3), 193.

Chatman, E.A. (1999). A theory of life in the round. Journal of the Association for Information Science and Technology, 50(3), 207.

Chatman, E.A., \& Pendleton, V.E. (1995). Knowledge gap, information-seeking and the poor. The Reference Librarian, 23(49-50), 135-145.

Childers, T., \& Post, J.A. (1975). The information-poor in America. Metuchen, NJ: Scarecrow.

Corker, M. (1999). Differences, conflations and foundations: The limits to 'accurate' theoretical representation of disabled people's experience? Disability \& Society, 14(5), 627-642. https://doi.org/10.1080/09687599925984.

Crewshaw, K. (1989). Demarginalizing the intersection of race and sex: black feminist critique of antidiscrimination doctrine, feminist theory and antiracist politics. University of Chicago Legal Forum, 1989,139-168.

Dunn, D.S., \& Andrews, E.E. (2015). Person-first and identity-first language: Developing psychologists' cultural competence using disability language. American Psychologist, 70(3), 255.

Eubanks, V. (2018). Automating inequality: How high-tech tools profile, police, and punish the poor. New York: St. Martin's Press.

Gibson, A.N. (2014). A better place? Factors in community assessment for parents of children with Down syndrome. Proceedings of the Association for Information Science and Technology, 51(1), 1-10. https://doi.org/10.1002/meet.2014.14505101063.

Gibson, A.N., Kaplan, S., \& Vardell, E. (2017). A survey of information source preferences of parents of individuals with autism spectrum disorder. Journal of Autism and Developmental Disorders, 47(7), 2189-2204. 
Giddens, A. (1984). The constitution of society: Outline of the theory of structuration. Berkeley, CA: University of California Press.

Goulding, A. (2001). Information poverty or overload? Journal of Librarianship and Information Science, 33(3), 109-111.Greyson, D. (2017). Health information practices of young parents. Journal of Documentation, 73(5), 778-802

Haider, J., \& Bawden, D. (2007). Conceptions of "information poverty" in LIS: A discourse analysis. Journal of Documentation, 63(4), 534-557.

Hasler, L., \& Ruthven, I. (2011). Escaping information poverty through Internet newsgroups. In Proceedings of the Fifth International AAAI Conference on Weblogs and Social Media (ICWSM) (pp. 153-160) Barcelona, Spain. Retrieved from https://www.aaai.org/ocs/index.php/ICWSM/ICWSM11/paper/view/2868.

Hill, H. (2013). Disability and accessibility in the library and information science literature: A content analysis. Library \& Information Science Research, 35(2), 137-142.

https://doi.org/10.1016/i.lisr.2012.11.002.

Hoffman, A. (2018). Data violence and how bad engineering choices can damage society. Retrieved from https://medium.com/s/story/data-violence-and-how-bad-engineering-choicescan-damage-society-39e44150e1d4.

Honma, T. (2005). Trippin' over the color line: The invisibility of race in library and information studies. InterActions: UCLA Journal of Education and Information Studies, 1(2). Retrieved September 27, 2018 fromhttps://escholarship.org/uc/item/4nj0w1mpIndividuals with Disabilities Education Act. 2004. 20 U.S.C.§1400 (U.S.A.).

Jaeger, P.T., \& Burnett, G. (2010). Information worlds: Social context, technology, and information behavior in the age of the Internet. NewYork: Routledge.

Jones, M.R., \& Karsten, H. (2008). Giddens 'structuration theory and information systems research. MIS Quarterly, 32(1), 127-157.

King, G., Zwaigenbaum, L., King, S., Baxter, D., Rosenbaum, P., \&Bates, A. (2006). A qualitative investigation of changes in the belief systems of families of children with autism or Down syndrome. Child: Care, Health and Development, 32(3), 353-369.

Kolb, S.M. (2012). Grounded theory and the constant comparative method: Valid research strategies for educators. Journal of Emerging Trends in Educational Research and Policy Studies, 3(1), 83.

Krieger, N., Williams, D.R., \& Moss, N.E. (1997). Measuring social class in US public health research: Concepts, methodologies, and guidelines. Annual Review of Public Health, 18(1), 341-378.

Lingel, J., \& Boyd, D. (2013). "Keep it secret, keep it safe": Information poverty, information norms, and stigma. Journal of the Association for Information Science and Technology, 64(5), 981-991. 
Mackintosh, V.H., Myers, B.J., \& Goin-Kochel, R.P. (2005). Sources ofinformation and support used by parents of children with autism spectrum disorders. Journal on Developmental Disabilities, 12(1), 41-51.

Mathiesen, K. (2015). Human rights as a topic and guide for LIS research and practice. Journal of the Association for Information Science and Technology, 66(7), 1305-1322.

Mervyn, K., \& Allen, D.K. (2012). Sociospatial context and information behavior: Social exclusion and the influence of mobile information technology. Journal of the Association for Information Science and Technology, 63(6), 1125-1141.

Noble, S. (2018). Algorithms of oppression. New York: NYU.

Noble, S.U., Austin, J., Sweeney, M.E., McKeever, L., \& Sullivan, E. (2014). Changing course: Collaborative reflections of teaching/taking "Race, Gender, and Sexuality in the Information Professions". Journal of Education for Library and Information Science, 55(3), 212-222.

Oliver, M. (2013). The social model of disability: Thirty years on. Dis-ability \& Society, 28(7), 1024-1026. https://doi.org/10.1080/09687599.2013.818773.

Orlikowski, W.J. (1992). The duality of technology: Rethinking the concept of technology in organizations. Organization Science, 3(3),398-427. https://doi.org/10.1287/orsc.3.3.398.

Pifalo, V., Hollander, S., Henderson, C.L., DeSalvo, P., \& Gill, G.P. (1997). The impact of consumer health information provided by libraries: The Delaware experience. Bulletin of the Medical Library Associa-tion, 85(1), 16.

Putnam, M. (2005). Developing a framework for political disability identity. (conceptualizing disability). Journal of Disability Policy Studies, 16(3), 188-199.

Samek, T. (2007). Librarianship and human rights: A 21st century guide (Chandos information professional series). Atlanta, GA: Neal-Schuman Publishers.

Savolainen, R. (1995). Everyday life information seeking: Approaching information seeking in the context of "way of life". Library \& Information Science Research, 17(3), 259-294.

Scotch, R.K. (2000). Models of disability and the Americans with Disabilities Act. Berkeley Journal of Employment and Labor Law,21, 213.

Sligo, F.X., \& Jameson, A.M. (2000). The knowledge-Behavior gap in use of health information. Journal of the Association for Information Science and Technology, 51(9), 858-869. https://doi.org/10.1002/(SICl)1097-4571(2000)51:9<858::AID-ASI80>3.0.CO;2-Q.

Solomon, P. (1997). Discovering information behavior in sense making. I. Time and timing. Journal of the American Society for Information Science, 48(12), 1097-1108.Sonnenwald, D.H.,

Wildemuth, B., \& Harmon, G.L. (2001). A research method to investigate information seeking using the concept of Information Horizons: An example from a study of lower socio-economic students' information seeking behavior. The New Review of Information Behavior Research, 2, 65-86. 
Star, S.L., \& Griesemer, J.R. (1989). Institutional ecology, translations 'and boundary objects: Amateurs and professionals in Berkeley's Museum of Vertebrate Zoology, 1907-39. Social Studies of Science, 19(3), 387-420.

Thompson, K.M. (2007). Furthering understanding of information literacy through the social study of information poverty. The Canadian Journal of Information and Library Science, 31(1), 87-115.

Tufekci, Z. (2017). Twitter and tear gas: The power and fragility of net-worked protest. New Haven, CT: Yale University Press.

Walker, C.G. (2009). Seeking information: A study of the use and under-standing of information by parents of young children. Journal of Information Literacy, 3(2), 53-63.

Wiegand, W.A. (1999). Tunnel vision and blind spots: What the past tells us about the present; reflections on the twentieth-century history of American librarianship. The Library Quarterly, 69(1), 1-32.

$\mathrm{Yu}, \mathrm{L}$. (2006). Understanding information inequality: Making sense of the literature of the information and digital divides. Journal of Librarianship and Information Science, 38(4), 229252. 